\title{
Learning Model of Multicultural Harmonization in Tolerance of Eleventh Grade in Sma Muhammadiyah 10 Surabaya
}

\author{
Muhammad Muharror $^{1}$ \\ ${ }^{1}$ Patoman, Keboharan 07/02, Krian, Sidoarjo, East Java, Indonesia
}

\begin{abstract}
Differentiation in nationality is necessity because the awareness of national identity forms a similarity of taste and fate. Multicultural harmonization and mutually reinforcing one with the other effect on the common are good and the strength of thenation. Tolerance is the cornerstone of a plural society. Many discourse differences in all aspects of the nation, raises the paradigm of disintegration and disintegration of the nation. The inter-group dichotomy adds to the endlessly war of debates between groups. The sample of recent discourse is the grouping of Indonesia nationalism (Pancasila) with the Islamic community invites considerable debate since Pancasila and Islam are cannot be separated. The fragmentation of politics cause clash between nationalism groups and religions up to the nation is nothing but the political maneuvers launched by irresponsible people and groups are take the split advantages of the Indonesian nation. With any difference in the cases with the participants of 36 student which chosen by the school as the research subjects. Those participants are in Eleventh grade in SMA Muhammadiyah 10 Surabaya. tries to receive any difference religion, ethnic, profession, disables and language. This school is one most school in Surabaya and east Java, the learning based on faith and good attitude as an organization Muhammadiyah. This research approaching methods research and development is based on Borg W.R. and Gall M.D. (2003). The finding of this research is nation's split has always been a topic that must focus on peace reconciliation and always be alert to the groups that want to divide the nation.
\end{abstract}

\section{Keywords: harmonization; multicultural; and tolerance}

\section{INTRODUCTION}

The diversity in Indonesia is a necessity and absoluteness of man. The ancestors of the Indonesian nation are already familiar with cultural unification even sometimes until religious rites become a very natural thing and not a percussion discourse. But lately, it seems to be a sacred and very exclusive thing to teach its people. Indonesia as the largest archipelagic country in the world is very vulnerable to national disintegration. The presence of both domestic and foreign threats is huge and alarming. Then all the children of the nation must be vigilant and always develop the unity and unity of the nation. The children of the nation must analyze history and struggle in founding the nation of Indonesia. 
Indonesia as a country so vast and rich in natural resources and diverse ethnic, cultural and religious make Indonesia a country highly respected by other nations in the world. Indonesia became the pilot of the life of a diverse society and able to live side by side in harmony and mutual respect since time immemorial. Indonesia is always known for its friendly community and always ready to be a good friend in the global world arena. Indonesia is also a model of a very moderate Muslim state beyond the middle eastern countries which is regarded as the beginning of the birth of the great religions of the world. Indonesia is so rich in natural and human products are very tolerant invite click amazed selurug nations in the world so unwittingly the threat of division caused by external factors also can not be denied. How many countries love us as well as those who hate us because of the gift of the most powerful god.

Diversity should be able to emphasize the importance of developing a tolerant attitude toward one another. Unfortunately, even tolerance is often accused of sacrificing certain religious fundamental values. In fact, tolerance in diversity is the key word for the realization of a civilized and just society of Indonesia. Tolerance is also a hallmark of human psychologist who from birth was tied up in a togetherness. Indeed, humans are always in touch with other humans in the container togetherness, friendship, work environment, neighborhood and neighborhood, as well as other forms of social relations. With the tolerant culture inherited from the ancestors and founding fathers of this country, we are directed to re-discover the identity as a human being with a high social spirit, requiring others as social beings (homo socius).

The success of our ancestors overcame differences in an elegant harmony, it should be our reference to re-see the others in a pluralistic frame. The Javanese proverb mangan ora mangan sing is important to collect (eat or not eat the most important is togetherness) not just a slogan, but has a philosophical content of the importance of intercourse. Even willing to sacrifice stomach affairs (eating) in order to maintain harmony of life. It is in harmony with the concept of Indonesian moyoritas religion is Islam.

Islam as a very tolerant religion is also able to embrace all the joints and religions that exist in Indonesia into a great unity and strength in the framework of the norms and values of noble universal virtues. Indonesia nation with multicultural and multiethnic based on Islamic values then perfect the concept of modern society is relegius and comprehensive with the development of the era. But in the subsequent development of Islam and the nation of Indonesia began undermined by the understandings that make the tribes divided. The understanding of the nation of indonsia about the tolerance of the mualai is obscured by the unscrupulous individuals who do not dare the nation of indoinesia in unity. The blasphemers of false news begin to embody a fact in hypocrisy.

The discourse on tolerance is highly relevant at any given time because humans are often tempted in disputes that weaken the power of unity and often the tendency to gain control over others. Tolerance is an important thing when a group begins to distrust the other group. In the concept of cultural science that change is a necessity that can not be changed, then the Indonesian nation must also be able to understand all the changes and cross the political, educational, cultural, social and economic constellation.

The concept of tolerance becomes a very important joint in nation and state. Nationalism will always grow when ethnic, tribal and religious tolerance is upheld. 
Nationalism in the history of the Indonesian nation is very strongly rooted and menajdi tradition ysecara hereditary. The Indonesian nation became more intolerant when it began to be loaded by corporations and the shrewd ideas of individualism and secularism. Cultural corporations began to press economy and then on other aspects of the Indonesian nation.

In terms of tolerance, Islam has a significant role in maintaining tolerance among religious people. Islam mediates from opposing poles. The predecessors of Islamic figures in Indonesia have taught the values of toletance and rational attitude. Islam became the biggest religion in Indonesia because of its very moderate attitude and upholding the values of diversity and tolerance. Islam comes with a pure and moderate system that is reflected in the attitude of tolerance.

\section{MUHAMMADIYAH IN EDUCATION}

Any further of development, Muhammadiyah schools become very diverse and colorful in teaching their students in the concept of religion and science. So, the concept of balance and logic are very pressed right in Muhammadiyah universities. Diversity of Indonesia and diverse background of people in Indonesia especially big cities like Surabaya making exclusive schools that are no longer relevant because of its heterogeneous societies have right now. The researcher tries to analyze schools Surabaya Muhammadiyah middle of a big city named SMA Muhammadiyah 10 of Surabaya or SMAMX which well-known and very new established since 2014 few years ago. The participants of 36 student which chosen by the school as the research subjects. Those participants are in Eleventh grade in SMA Muhammadiyah 10 Surabaya.

The concept offered by the school and rational are discusses in today's pragmatism understanding and concepts of education. The combination between science and religion become a comprehensive center gravity of thinking in addressing any problems that exist in Indonesia. The educational model adopted by SMA Muhammadiyah 10 of Surabaya refers to the concept of integrated advance learning of science and ethics.

This research is to develop teaching materials with a history of values-based openwork embroidery style to improve the character of students. In compiling, this study using research and development approach known Research and Development (R \& D). According to Borg and Gall [1] argues "Educational Research and Development (Educational $R \& D$ ) is an industry-based development models in the which the findings of the research are used to design new products and procedures, the which then are systematically field-tested, evaluated, and refined until they meet specified criteria of effectiveness, quality, or similar standards" according to Ridho (2012:7).

According to Borg \& Gall [1] research and development procedure basically consists of two main objectives, namely to develop the product and test product effectiveness in achieving goals. The first objective is referred to as a function of development, while the second is referred to as validation functions. To more clearly Borg and Gall [1] research procedures consisted of 10 steps, record steps are summarized below: 


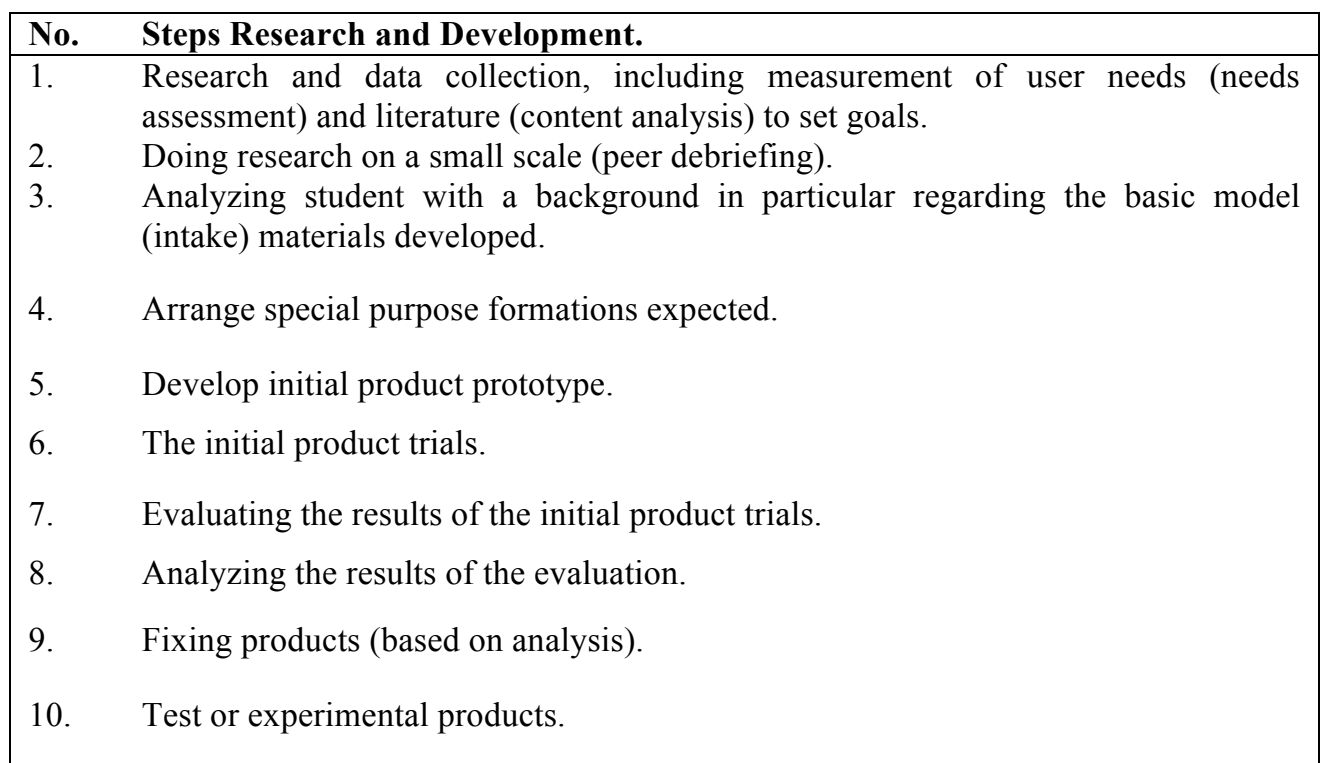

The learning process in the classroom during these process tend to use one-way communication, that information comes only from teachers towards students, resulting in students being less actively involved in learning activities such as sharing ideas and experience is responsible for the task, receptivity better opinion, ask questions, and bring in "experts" to the class, or that more bad news is they are reducing the learning achievement.

In a historical context, Muhammadiyah as a mass organization who has wishes to realize the teachings of Islam which is more returns to the pure Islam, the Islam that was taught by the Prophet Muhammad, based on Al-Quran and al-Hadith, not based on local culture which is not necessarily in accordance with the teachings of Islam, instead could be assessed had deviated from Islamic teachings. This is evidenced by Muhammadiyah through $d a$ 'wahwhich has done in many ways and more modernist. Efforts to realize this establishing constitutions formal education that blends patterns of western secular education with Islamic education in harmony with the teachings of al-Quran and al-Hadith that found many educational institutions Muhammadiyah looks more advanced and more toward creating Insankamil's learning Islam. In the discourse of politics, Muhammadiyah has been active since the days of the Dutch East Hindi; he tried to provide resistance to the colonial government with various efforts, whether through fund-Muslims in order to demand independence. In the movement of thought can be distinguished on revivalism, secularism and modernism.

Buya Syafi' $i$ [2] Talk about Muhammadiyah is not independent with motion of thinking character which Buya Syafi'I said. His thoughts are influenced by models of neo-Modernist approach: first, the formulation of the world view of the Koran. Second, create a systematic analysis of the moral teachings of the Qur'an and in turn will create the ethics of the Koran. Third, formulate legal systems and formulas are aligned with the needs of the contemporary popularity of such ethics. Direction of movement is taking shape on a hypothesis about the renaissance of Islam spreading in the world is emerging as a strong reaction against the traditional scholars weaknesses and failures of Islamic countries in tackling the influence of the West.

Buya Syafi'I through four things into his turmoil which: first, he was not willing if this nation torn by religious politics, interests, local and primordial. Second, the 
gap between teaching and practice of life is named the lack of correlation between religious practices and moral improvement. On the one hand, the diligent worship, on the other hand, the spread more corruption and violence destroy this nation. Third, the emergence of diseases this is culturally and mentally. Fourth, the phenomenon of poverty and ignorance override largely Muslim Indonesia. Against four things into the unrest, then it becomes important keywords raised was about the interrelationship between Islam, humanity, and Indonesians. The reception will be an intimate correlation-third will pave the way toward Islam that should be developed in Indonesia. Development of a model-ideal top three would provide the right solutions to the problems that afflict the nation and the country. To formulate the ideal pattern of relationships, Buya Syafi'i thrusting propositional assumptions that first, Indonesian Islam must be based on a model of a peaceful Islam, because Islam thus initially entrance and an important part of the lives of the people of Indonesia. This peaceful means should be able to give shades of Islam that is open, calms and gives comfort to groups of other religions. Secondly, history shows that the founding fathers of this nation, who are mostly Muslims, both struggling in the realm of party or nationalist movement, the de facto accept the political system of democracy, while democracy is still a lot of weaknesses. Third, democracy cannot be separated from the acceptance of plurality and tolerance. In this context of problem in order to finds the basic state into a prolonged polemic between Pancasila and Islam. And Muhammadiyah and NU has accepted Pancasila as the state of Indonesia, as well as leaving the Jakarta Charter and reject the Khilafah Islamiyah. Fourth, the future of religion lies in the attempt ijtihad.

The role of education is not important only in its pragmatic purpose, but also in emphasizes the acquisition of knowledge and prepare to get job opportunity for improving welfare. Islam wants to fight against ignorance and poverty most of his time. Additional pressure is an education geared to help develop reasoning skills in order to be able to account statements, beliefs and actions. In any event, any religion becomes an initiator in the international world. It shows that religion is able to answer the challenges of change of time is an important component of the formation of tolerance and integrity of the Indonesian nation amidst the many propaganda and stimulation of perfehan which is blown by irresponsible elements.

Within various difficulties and threats from the nation outside Indonesia which was formerly named archipelago, this nation continues to spread and continue to spread the goodness and unity between ethnic and religious. Islam as the majority religion in Indonesia has a share in maintaining the diversity and multicultural that exist in Indonesia. But the religion of Islam and other religions must also be able to answer the development of the era and all kinds of problems that occur in society. Society must also be able to develop the identity of religious identity and the nation of Indonesia as a whole and balanced.

Religion must also be present as a religion that protects the totality of all aspects of life with the concept of spreader of love (rahmatan lil alamin or memayu hayuning buwono) and also other religions. But if the role has not been able diemban by diverse communities. Sooner or later, the position of religion as a source of religiosity transforms into a "ghost of theology" that threatens the unity and unity of the nation. Religion has degenerated because it no longer seeks the truth, but merely maintains a belief system. In the end, diversity is perceived as a dangerous rival and as much as possible muffled in various ways though it must pass through the 
unconstitutional behavior. The power elite succeeds in creating an identity politics so that the society's perspective on diversity becomes segmental.

Consequently, our awareness to see the other (as others) as human beings who need to be respected regardless of confidence becomes blurred. The climax of all of them raises a blind fanaticism characterized by the inability of a particular person or group to prioritize discussion, but rather prioritizes coercion because they feel themselves to be the most correct human beings. It is still minimal awareness of this nation that religion is a private matter that no one has the right to regulate and interfere. Private interests should no longer be the subject of endless debate. By interfering in private affairs, an understanding of plurality or the existence of the others becomes obscure or indeed we have no readiness to see and appreciate differences.

Perhaps, some societies have now forgotten that this nation has so many stories or history laden with philosophical content, especially in terms of preserving plurality. It should be an inspiration to re-emerge noble values in caring for diversity. The spirit of diversity as initiated by Mpu Tantular in his book Sutasoma, teaches humans to consistently guard and safeguard the pluralism that is the foundation of the concept of nation state (nation state). This spirit of togetherness is a value that has already been internalized in society long ago. Our ancestors have come to realize that human beings are born not just from biological processes between husband and wife, but human birth in essence indicates a deep relationship with others.

\section{CARING FOR DIVERSITY}

Man was born in order to discover his uniqueness as person. One of the fundamental factors for my unique establishment is the ability to socialize with others and the environment. The I-Thou-Relation-He is not a subject-object relationship, but subjects. This is the relationship Martin Buber called "Ich un Du". Here there is no objectivation. It is very different from the mutually objectionable relationship of Sartre (the objects). Or by Hobbes termed homo homini lupus (humans are wolves to others). In the subject-object relation, humans easily fall in an egoistic friction.

Indeed human beings need appreciation, but if not controlled, will lead to a vortex of self crisis, that is egoism. Egoism is a self-centered attitude. He does not pay attention and tends to negate others. Even under certain conditions, this egotistical behavior can lead to the use of others as a means or object for the fulfillment of self-interest. In other words, egoism is a new respect for others when running our demands for the realization of self-interest. This kind of egoistic tendency makes the offender lose the opportunity to express the values of life within. Regard to egoism, humans now tend to be egotistical and rude because they lose the grip of respect. The (formerly) thing is such absolute is now relative. Even considered not sold again in the context of the modern world. Practically, this kind of condition prevents humans from touching each other with courtesy and without prejudice. It is not easy to understand and accept others with all the difference. But it is precisely because of that humans are required to establish interaction and relationships with each other or the others. The differences that exist in human beings are not a reason to live alone, let alone negate the diversity.

With cases that seem to threaten our diversity of late, it is hoped to all parties, to turn back the memory of how these central fighters and figures of the country were 
once deeply appreciative of the differences and fought together for the establishment of the Unitary State of the Republic of Indonesia. We who live today should be able to take care of this diversity in order to maintain the unity and unity of the country and dismiss the power ego that is not in the corridor of law.

To sum up, multicultural harmonization and mutually reinforcing one with the other effect on the common are good and the strength of the nation. Tolerance is the cornerstone of a plural society. Many discourse differences in all aspects of the nation, raises the paradigm of disintegration and disintegration of the nation. The inter-group dichotomy adds to the endlessly war of debates between groups. The sample of recent discourse is the grouping of Indonesia nationalism (Pancasila) with the Islamic community invites considerable debate since Pancasila and Islam are cannot be separated. With any difference in the cases of Eleventh grade with 36 participants, SMA 10 Muhammadiyah Surabaya tries to receive any difference religion, ethnic, profession, disables and language. This school is one most school in Surabaya and east Java, the learning based on faith and good attitude as an organization Muhammadiyah. The finding of this research is nation's split has always been a topic that must focus on peace reconciliation and always be alert to the groups that want to divide the nation.

\section{REFERENCES}

[1] Borg W.R. and Gall M.D. 2003. Educational Research: An Introduction. London: Longman, Inc

[2] Ahmad Syafii Maarif. 2006. Islam Dalam Bingkai Keindonesiaan dan kemanusiaan. Bandung. Mizan

[3] Abdul Munir Mulkhan. 2010. Jejak Pembaharu Islam dan Kemanusiaan Kiai Ahmad Dahlan. Jakarta, Kompas.

[4] Binhad dan Shofwan dkk.2009. NUhammadiyah bicara Nasionalisme. Yogyakarta. Aruz Media

[5] Ben Anderson.2001. Imaged Communities. Yogyakarta.Pustaka Pelajar

[6] Moh. Ali. 2005. Pengantar Ilmu Sejarah Indonesia. Yogyakarta: Lkis.

[7] Kuntowijoyo.(1995).Pengantar Ilmu Sejarah.Yogyakarta:Yayasan Bentang Budaya.

[8] Sugiyono. 2013. MetodePenelitianKuantitatif, Kualitatifdan R\&D. Bandung: Alfabeta.

[9] Sartono Kartodirdjo. 1992. Pendekatan Ilmu Sosial dalam Metodologi Sejarah. Jakarta: Gramedia Pustaka Utama.

[10] Trianto. 2010. Model Pembelajaran Terpadu Konsep, Strategi dan Implementasinya dalam Kurikulum Tingkat Satuan Pendidikan (KTSP). Jakarta: BumiAksara.

[11] Kamal ahmad khan. (2011). "The concept of tolerance in Islam", the Milli Gazette..no 28. 